\title{
Eosinophilic pleural effusion with high anti-DNA activity as a manifestation of systemic lupus erythematosus
}
A. J. WYSENBEEK
M.D.
A. I. PICK*
M.D.
A. SElla
M.D.

\author{
Y. BEIGEL \\ M.D.
}
D. YESHURUN
M.D.

\begin{abstract}
Department of Internal Medicine ' $B$ ' and * Section of Clinical Immunology, Beilinson Medical Center, Petah Tiqva, and the Sackler School of Medicine, University of Tel-Aviv, Ramat Aviv, Israel
\end{abstract}

\begin{abstract}
Summary
A patient, known to have systemic lupus erythematosus (SLE), presented with an eosinophilic pleural effusion. It is believed that SLE was the cause of her pleural effusion as increased levels of anti-DNA activity were found in the pleural fluid. Eosinophilic pleural effusion is a previously unreported observation in SLE patients (so far as the authors are aware), and the existence of increased anti-DNA activity in the pleural fluid may have value as an additional aid in the diagnosis of this disease.
\end{abstract}

\section{Introduction}

The diagnostic criteria for SLE have been established by the American Rheumatoid Association (Cohen et al., 1971). Increased serum anti-DNA activity has been found to be important both in early detection and diagnosis of this disease (Pincus et al., 1969).

A patient diagnosed 6 months previously as having SLE, presented with a pleural effusion containing $30 \%$ eosinophils. Although pleural effusion is a common sign in SLE (Dubois and Tuffanelli, 1964), eosinophilic pleural effusion has, to the authors' knowledge, not yet been reported in this condition. Increased anti-DNA activity in the pleural fluid led to the suspicion that the aetiology of the eosinophilic effusion was SLE.

\section{Case report}

A 51-year-old Caucasian woman was admitted to the medical service because of skin eruptions. Six months earlier the diagnosis of SLE had been established on the basis of painful symmetrical joint swelling, the repeated finding of LE cells, a positive anti-nuclear factor (ANF) to a titre of $1: 20$ and a

Correspondence: Dr D. Yeshurun, Dept of Internal Medicine 'B', Beilinson Medical Center, Petah Tiqva, Israel. history of thrombocytopenia and Raynaud's phenomenon. In view of her good general condition and absence of renal involvement she was discharged without any special treatment.

The patient was readmitted because of a rash which had appeared a few days before admission. Physical examination revealed a healthy looking woman with a diffuse erythematous maculopapular rash on both arms and chest. The palms were spared and there was no pruritus. She was apyrexial.

Laboratory investigations yielded the following results: ESR $26 \mathrm{~mm} / \mathrm{hr}$ (Westergen); haemoglobin $12.3 \mathrm{~g} / \mathrm{dl}$; WCC $5.9 \times 10^{9} / 1$ with a differential count of $62 \%$ neutrophils, $33 \%$ lymphocytes, $4 \%$ monocytes and $1 \%$ eosinophils; platelets $220 \times 10^{9} / 1$. Blood urea nitrogen, electrolytes and liver function tests were all normal. Total protein was $66 \mathrm{~g} / \mathrm{l}$ with $37 \mathrm{~g} / 1$ albumin. Immunoelectrophoresis and urinary sediment were normal. Repeated stool tests revealed no parasites. No LE cells were found and the ANF was positive to a titre of $1: 20$. Complement $\mathrm{C}_{3}$ levels were $1.42 \mathrm{~g} / \mathrm{l}$ (normal $0.93-2$ ) and $C_{4}$ levels were $0.52 \mathrm{~g} / 1$ (normal $0.3-0.6$ ). No anti-DNA activity was detected in the serum and IgE concentration was 142 i.u.

During this admission the rash improved spontaneously but on the fifth day physical signs of bilateral pleural effusion appeared. After X-ray confirmation, a diagnostic pleural aspiration produced clear, sterile, yellow fluid with a protein content of $37 \mathrm{~g} / \mathrm{l}$. Microscopic examination disclosed $30 \%$ eosinophils, the remaining cells being polymorphonuclear leucocytes, monocytes, lymphocytes, histiocytes and a few mesothelial. No LE cells were detected in the exudate. ANF was positive to a titre of $1.40 ; \mathrm{C}_{3}$ was $0.375 \mathrm{~g} / \mathrm{l} ; \mathrm{C}_{4}$ was $0.03 \mathrm{~g} / \mathrm{l}$; anti-DNA activity $29 \%$ and IgE 175 i.u. (Table 1 ).

The patient remained asymptomatic and received no treatment. The pleural effusion cleared gradually 
and chest X-rays showed no sign of effusion 2 weeks later.

\section{Discussion}

Pleural effusion is a common finding in a great variety of diseases, including rheumatoid arthritis (RA) and SLE. In spite of the many diagnostic aids available, such as protein content, cell type in the sediment, LE cells, rheumatoid factor, complement and glucose concentration (Dubois, 1974), there are still patients in whom the differential diagnosis between RA and SLE is difficult to establish.

TABLE 1. Summary of laboratory results

\begin{tabular}{lcc}
\hline & Serum & Pleural fluid \\
\hline Eosinophils & $1 \%$ & $30 \%$ \\
LE cells & negative & negative \\
ANF & $1: 20$ & $1: 40$ \\
Total protein & $66 \mathrm{~g} / \mathrm{l}$ & $37 \mathrm{~g} / 1$ \\
C $_{3}$ & $1.42 \mathrm{~g} / \mathrm{l}$ & $0 \cdot 375 \mathrm{~g} / \mathrm{l}$ \\
C $_{4}$ & $0.52 \mathrm{~g} / \mathrm{l}$ & $0.03 \mathrm{~g} / 1$ \\
Anti-DNA & $0 \%$ & $29 \%$ \\
IgG & $16 \mathrm{~g} / 1$ & $9 \cdot 2 \mathrm{~g} / 1$ \\
IgA & $4.6 \mathrm{~g} / 1$ & $2 \cdot 25 \mathrm{~g} / 1$ \\
IgM & $>3 \mathrm{~g} / \mathrm{l}$ & $2 \cdot 35 \mathrm{~g} / \mathrm{l}$ \\
IgE & $142 \mathrm{i} . \mathrm{u}$. & $165 \mathrm{i} . \mathrm{u}$. \\
\hline
\end{tabular}

Increased serum anti-DNA activity is considered a very good indicator for activity in SLE, especially in relation to renal involvement (Hill et al., 1978). No data describing pleural fluid anti-DNA activity were found in those patients. The increased antiDNA activity found in the present patient's pleural effusion supports the assumption that the cause of her effusion was SLE. This finding may be another aid in the differential diagnosis of pleural effusions in general, and in patients with collagen disease in particular. In view of the absence of anti-DNA activity in the serum it would seem apparent that normal serum anti-DNA titres do not exclude lupus activity, especially if manifested by pleural involvement.

Eosinophilic pleural effusion is a relatively rare phenomenon. It is defined as the presence of $10 \%$ or more eosinophils in the pleural fluid, exclusive of erythrocytes (Kokkola and Valta, 1974). Campbell and Webb (1964) described 7 such cases, and summarized 101 additional patients from the literature. According to their review the aetiology of eosinophilic pleural effusion is as follows: $28 \%$ idiopathic, $24 \%$ post-traumatic, $16 \%$ hypersensitivity related, $14 \%$ due to malignancy, $11 \%$ related to pulmonary infarction, cirrhosis and sarcoidosis, and $2 \%$ to rheumatoid arthritis. No cases of SLE were reported. Bower (1967) described 21 additional patients with eosinophilic pleural effusion. One of these had a 'rheumatoid disease', with positive LE cells in the peripheral blood, but the pleural effusion was probably related to pulmonary infarction. Six additional reports of eosinophilic pleural fluid in $c$ rheumatoid arthritis were later published (Campbell and Ferrington, 1968; Kokkola and Valta, 1974).

The pathophysiology of the formation of eosinophilic pleural fluids is not yet fully known. The high correlation with chest trauma was attributed to the fact that the stroma of the red blood cells has been shown to contain a protein-carbohydrate eosinophilotactic compound (Chapman, 1961). There is evidence of bronchogenic carcinoma secreting an eosinophilotactic factor (Wasserman, Goetzel and Aisten, 1974), and eosinophils are known to accumulate as a response to immune complexes (Cohen and Ward, 1971).

Two conclusions may be drawn from this report. Firstly, increased anti-DNA activity may be detected in pleural effusions and, therefore, serve as an additional aid in the diagnosis of such effusions occurring in patients with collagen diseases; secondly, SLE should be added to the above list of aetiologies of eosinophilic pleural effusion.

\section{References}

Bower, G. (1967) Eosinophilic pleural effusion. American Review of Respiratory Diseases, 95, 746.

CAMpbell, G.D. \& FerRington, E. (1968) Rheumatoi pleuritis with effusion. Diseases of the Chest, 53, 521.

Campbell, G.D. \& WebB, W.R. (1964) Eosinophilic pleurat effusion. American Review of Respiratory Disease, 90, 194.

Chapman, J.S. (1961) Effect of solvents on eosinophilstimulating substance of erythrocyte stroma. Proceedings of the Society for Experimental Biology and Medicine, $108,566$.

Cohen, A.S., Raynolds, W.E., Franklin, E.C., Kulka, J.P., Ropes, M.W., Shulman, L.E. \& Wallace, S.L. (1971) Preliminary criteria for the classification of systemic lupus erythematosus. Bulletin on the Rheumatic Diseases, 21, 648 .

COHEN, S. \& WARD, P. (1971) In vitro and in vivo activity of a lymphocyte and immune complex-dependent chemotactic factor for eosinophils. Journal of Experimental Medicine, 133, 133.

DuвoIs, E.L. (1974) In: Lupus Erythematosus, 2nd edn, p. 405, University of Southern California Press, Los Angeles.

Dubois, E.L. \& Tuffanelli, D.L. (1964) Classical manifestations of systemic lupus erythematosus. Journal of the American Medical Association, 190, 104.

Hill, G.S., Hinglais, N., Tron, F. \& Bach, J.F. (1978) Systemic lupus erythematosus, morphologic correlations with immunologic and clinical data at the time of biopsy. American Journal of Medicine, 64, 61 .

Kokkola, K. \& Valta, R. (1974) Aetiology and findings in eosinophilic pleural effusion. Scandinavian Journal of Respiratory Diseases, suppl. 89, 159.

Pincus, T., Schur, P.H., Rose, J.A., Decker, J.L. \& TAlal, N. (1969) Measurement of serum DNA binding activity in systemic lupus erythematosus. New England Journal of Medicine, 281, 701.

Wasserman, S.I., Goetzel, E.J. \& Aisten, K. (1974) Tumor-associated eosinophilotactic factor. New England Journal of Medicine, 290, 420. 